\title{
Export Credit Insurance and Export Performance: An Empirical Gravity Analysis for Turkey
}

\author{
Ali Polat ${ }^{1,2} \&$ Mehmet Yeşilyaprak ${ }^{3}$ \\ ${ }^{1}$ King Saud University, College of Business Administration, Riyadh, Kingdom of Saudi Arabia \\ ${ }^{2}$ Prime Ministry of Turkey, Senior Advisor, Ankara, Turkey \\ ${ }^{3}$ Turk Eximbank, Istanbul, Turkey \\ Correspondence: Ali Polat, Prime Ministry of Turkey, Ankara, Turkey. E-mail: apolat@ hotmail.com
}

Received: May 17, 2017

Accepted: June 15, 2017

Online Published: July 5, 2017

doi:10.5539/ijef.v9n8p12

URL: https://doi.org/10.5539/ijef.v9n8p12

\begin{abstract}
The paper attempts to find out how far Turkey's official export credit agency, Turk Eximbank, foster export of Turkey during the years of 2000-2015 by employing an empirical trade gravity equation. We estimate different panel gravity regressions for 212 countries for the period of 16 years and the results reveal that a change in export credit insurance positively affect Turkish export, assuming other independent variables are held constant. After applying several post estimation tests we used fixed effect panel specification as the main estimation. In order to allow comparison we also run clustered, robust OLS. Poisson fixed effect (Poisson) and Poisson Pseudo maximum likelihood estimations (PPML) are also estimated to allow for zero trade values in dependent variable in its level. Our analysis also shows that there are significant individual and time effects in panel data structure. Our estimate of different panel gravity regressions for 212 countries and 16 years revealed that increasing export insurance will positively affect Turkish export.
\end{abstract}

Keywords: Turkey, Turk eximbank, gravity, trade promotion, credit insurance

\section{Introduction}

Export promotion is a much discussed topic of trade finance in practice as well as in the theory of international trade. Free trade proponents claim that export promotion undermines the multilateral system and distorts competition while advocates of such agencies claim that availability of the independent official organizations strengthens the export position of export companies. (Abraham \& Dewit, 2000) Although trade credit decision is complex (Ross \& Pike, 1997) Auboin (2009) indicates that 80 to 90 percent of all exports rely on a form of trade finance or credit. That much reliance on trade credit will create a dependency and have a potential disruptive role in case of financial frictions in the global credit markets. Whether global markets are smooth or under stress, exporter firms utilize export credit insurance to protect themselves from a risk of payment default. Imperfection in the credit market restrain exports particularly if the sectors rely strongly on external finance. (Manova, Wei, \& Zhang, 2015).

The provider of export credit insurance is usually a state-owned or private organization. Egger and Url (2006) indicate cross border trade credit insurance has been a domain of public export credit agencies until the beginning of the 1980s as private insurance companies were reluctant to undertake this risk. Felbermayr (2013) explains the reason why public export credit agencies were able to provide such services although under current WTO norms such export subsidies would be outlawed: WTO Agreement on Subsidies and Countervailing Measures exempt export insurance credit schemes if a sufficiently large number of GATT members are members of an "international undertaking on official export credits" that regulates the use of those guarantees.

Over 50 countries have ECAs and they have similar product to promote export. WTO objective and supplemental agreements like the Arrangement on Guidelines for Officially supported export credits require ECAs to break even in the long term. (del Carmen García-Alonso, Levine, \& Morga, 2004).

Turkey has adopted an export growth strategy in the beginnings of 1980s. The production of Turkey has shifted from agricultural goods to industrial goods which required financing for exporters. Chartered by the Cabinet on the $21^{\text {st }}$ August 1987. (Turk Eximbank, 2017) Turk Eximbank is a fully state-owned bank performing as the export incentive instrument in Turkey's sustainable export strategy. (Turk Eximbank, 2016). 
Following Turkey's agreement to remove export subsidies and elimination of all direct incentives to export as per GATT/WTO provisions, the role that Turk Eximbank played to secure a stable export growth experience has crucially increased. Turk Eximbank is a full member of the Berne Union since April 1994, the founder member of the Aman Union since 2009 and represents Turkey at the Group on Export Credits and Credit Guarantees of the OECD. In addition to these international aspects, Turk Eximbank commits to confirm OECD Consensus (although he is not a signed party of the Consensus) and harmonized its legislations in accordance with the EU requirements. Turkey is not a party in OECD (2016), Arrangement on Officially Supported Export Credits (also known as Knaepen Package). The arrangement focus on to stop the issuance of state-guarantees on trade credits distorting competition in the export insurance industry. The bank has credits, international loans, export credit insurance and some new instruments to increase the export of Turkish sellers. The bank does not have a consistent and comparable sectoral distribution of the insured exports with Turkish Statistical Institute data.

In this paper, official Turk Eximbank data is utilized. Turkish Eximbank has provided us with the all population of short term export insurance transactions extended during the period of 2000-2015. Total of 212 countries for 16 years counts 3392 observations in our dataset. Although the data obtained from Turk Eximbank provide details about the coverage amount granted to each buyer, export destination and industry there is a standardization problem in Turk Eximbank data which prevent us to make comparison on sectoral level between Turkish export and Turk Eximbank short term export insurance transactions. This study does not include any firm level or sectoral information. Meanwhile Figure 1 gives an insight regarding the sectoral distribution of exports insured under Short Term Export Credit Insurance Program. Figure 1 clearly indicates that Turkish export has a concentration in its export and two most important exports are textile/ready-to-wear/leather and machinery/electrical appliances and metal.

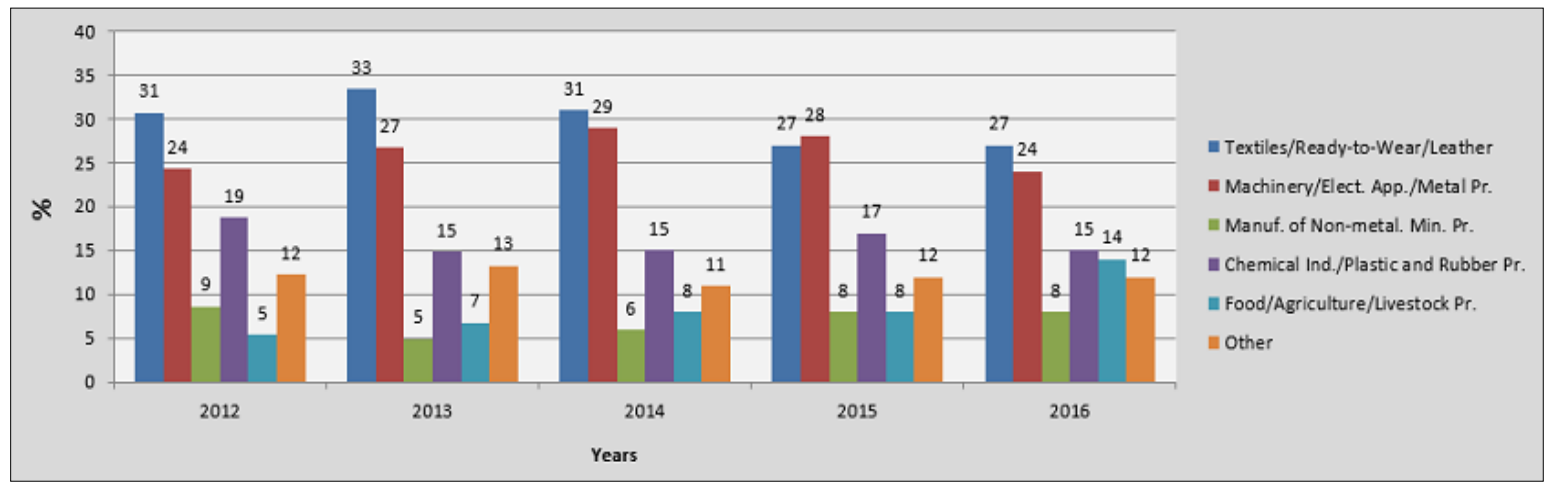

Figure 1. Sectoral distribution of exports insured under short-term export credit insurance program (\%)

Although there are papers analyzing the effect of export credit insurance on export regarding Germany (Felbermayr \& Yalcin, 2013; Moser, Nestmann, \& Wedow, 2008), Austria (Egger \& Url, 2006), there is no research made by using Turk Eximbank data. Ata (2013) analyses Turkey's trade with neighbor countries through a gravity equation. His findings indicates that Turkey's export with the neighbor countries is below potential and there is a room to increase the export. In this paper our interest is whether Turk Eximbank export credit insurance produces a significant amount of additional exports for Turkey. We have many of the standard gravity variables together with related dummies.

The paper is organized as follows. The following section is literature review. Section 3 gives information about our data and methodology used. Then we discuss empirical results in Section 4 and Section 5 is the details of the estimations used in Table 3. Section 6 is the conclusion.

\section{Literature Review}

One of the early studies regarding the topic belongs to Ross and Pike (1997). They employ a survey of Canadian export credit managers to understand how the export credit decision is made. Their findings demonstrate that existing trade credit models are insufficient to explain the export credit decision. Trade credit offer decision in an exporting firm is effected by export specific risks although they are not as important as standard credit risks in the trade credit decision. Still, export specific risks account for a good proportion of the variance in the trade credit model. The above given approach is also one of the reasons why ECAs are created by the governments.

Abraham and Dewit (2000) provide a theoretical, institutional and econometric assessment of the 
multidimensional objective function of a typical official export insurance agency by using Belgian OEIA data. They found in their regression analysis covering the period from 1984 to 1993 that export promotion does not necessarily imply trade distortion.

Garcia-Alonso, Levine and Morga (2004) analyze the role played by export credit guarantees in encouraging exports to developing countries. They relate export credit to moral hazards and export quality in their theoretical attempt. Verifying the actual quality of the export product will limit its ability to encourage trade through ECGs. Their result suggest that export credit guarantee may encourage risk-averse firms to trade with countries which might have political risks. The scope for trade may also decrease as the credit guarantee may increase the incentive of firms to export low quality. That result suggests us an interesting policy answer that excessive level of coverage will have a negative impact on trade. What they also discuss that trade is not necessarily encouraged by higher insurance coverage.

Egger and Url (2006) investigated export guarantees effect on trade volumes for goods exports from Austria for the period 1996 through 2002. The analyses they made include several models with full sample, no outliers, AR(1) and AR(1)-no outliers. Their 2-digit NACE panel data reveals that export guarantees have a significant short-term effect on export activity. Newly covered export credit creates additional short-term exports around 25 percent to 40 percent.

Mah (2006) examined whether or not export insurance subsidy of Japan has encouraged Japan's export supply. The unit root tests and cointegration analysis showed that export insurance system has not contributed to promoting export supply in Japan although Japan has been the heaviest user of the export insurance system.

Moser, Nestmann and Wedow (2008) investigate the claim that Hermes (German public export credit) guarantees mitigate the resistance to trade flows arising from hidden transaction cost as a result of political risk. By employing an empirical trade gravity model for 130 countries over the period 1991 to 2003 they estimate the effect of guarantees in a static and dynamic panel model. Their results present that political risk is a robust determinant of exports and should be taken into consideration in any trade related model.

Baltensperger and Herger (2009) tried to answer how far public export insurance schemes foster international trade and reached the conclusion that OECD countries issuing trade credits with state guarantees did not witness more exports towards politically and commercially more unstable low income countries. Rather, it has promoted exports towards high and middle income countries. In the period they investigated, 1999-2005, the risk of foreign default continues to impede international trade in countries suffering from aggravated levels of political and commercial instability. Such an outcome is another distortion to international trade as the high and middle-income countries have already developed financial intermediaries and markets that provide viable alternatives to hedge against payment risks.

It is a good point to mention that the literature has a clue that distribution of export credit insurance of the ECAs are biased. The less developed countries receive a less portion of the ECA credits while they need more of it. Developing countries owe a huge amount of debt to ECAs and it is a critical aspect for developing countries in terms of debt sustainability. These countries are not relieved by rescheduling of the debt.(Blackmon, 2014)

Head, Mayer and Ries (2010) analyzed the effect of independence on post-colonial trade by using bilateral trade data from 1948 to 2006. The paper suggests that there is a negative correlation between colonial independence and trade.

Herger and Lobsiger (2010) endeavor to discover how far officially backed guarantees on trade finance achieve their stipulated goal of promoting exports. Their results on gravity equations on Swiss Export Risk Insurance Scheme data for the years from 2006 to 2008 show that the scheme increases exports in the manufacturing sector by around 1 per cent. The positive effect of export guarantee increases for some emerging countries like Russia, Iran, Turkey, Mexico, or Indonesia as well as in some sectors like chemical and machinery industry.

Badinger and Url (2013) analysis the effects of export credit guarantee usage on trade for a new cross-sectional data of Austria for the year 2008. In their sample, the companies that use public export credit guarantees are large, stand-alone domestic firms with a high R\&D intensity and a high risk exposure.

Janda, Michalikova, and Skuhrovec (2013) analyzed a panel of 160 countries for the years from 1996 to 2008 by employing two gravity models of exports for the Czech Republic. They show through Least Trimmed Squares estimator that guarantees are a significant factor that influences the volume of exports in the Czech Republic positively with a leverage point.

Felbermayr and Yalcin (2013) empirically analyzed export credit guarantees and export performance for Germany for the years from 2000 to 2009. The study showed that export guarantees positively affect export 
volumes. Felbermayr and Yalcin (2013) also stress that there is a concentration of export guarantees for limited number of sectors and export destinations. They found that one per cent increase in Hermes guarantees boosts exports on average by about 0.012 per cent.

Auboin and Engemann (2014) employed Berne Union data on export credit insurance for the period of 2005-2011. They identify a significantly positive effect of insured trade credit on trade. Using an instrumentation strategy they found that the effect of insured trade credit on trade is very strong and remains stable over the cycle.

Veer (2014) used data for the period from 1992 to 2006 of a large credit insurance company and its export credit insurance for 25 OECD countries for exports to 183 countries worldwide. Applying various trade models, he found a positive and statistically significant effect of private export credit insurance on export. The results suggest that the private export credit insurance effect on trade is larger than the value of export insured. Due to the multiplicator effect, each euro of insured export generates around 1.3 euros of exports.

Eck, Engemann and Schnitzer (2014) show that firms intensively use cash-in-advance because it serves as a quality signal that reduces the high uncertainty related to international transactions. In their model, asymmetric information problems discourage less productive firms from exporting if only bank financing is available for these firms. However, if cash in advance is provided by foreign buyer that reduces the asymmetric information problem and thus promotes the export participation of firms that are not able to export with traditional bank financing. This result inherently include that if the asymmetric information problem is discouraging the transaction to happen, then exporters can be provided for export insurance for those importers who can't provide cash in advance.

Brunner (2015) analyzed the effect of imperfections in the formal export credit and insurance market on trade growth in the regions of Africa and Asia by using a panel data regression on quarterly data for the period 2005 to 2012. Their research identified a significantly positive effect from the reinforcing interaction of the export credit and insurance market, and export diversity-complexity on trade.

Brandi and Schmitz (2015) use a two-stage instrumentation approach to investigate the effect of the availability of trade finance on trade for the period 2005-2013 by using Berne Union data. Their one sided gravity model of trade results suggest that a one per cent increase in commitments is followed by a $0.27-0.54$ per cent increase in total imports in the next year. Trade openness is also important to encourage a healthy importer-exporter relation. When a country is more open to trade, the more frequent exchanges of goods support reliable importer-exporter relationships, so that trade partners do not have to rely as much on trade finance instruments.

Agarwal and Wang (2016) investigates the impact of US Export-Import Bank on US exports by using a three dimensional panel of 226 countries, 94 industries and 7 years spanning from 2007 to 2013. In their gravity framework on a country-industry-year level panel dataset, their results depict the general ineffectiveness of the Bank in promoting exports within and across industries. Their findings also reveal that industries other than aerospace parts and products are more likely to benefit from the Eximbank authorizations and that Eximbank authorizations to larger businesses seem to be more effective in encouraging exports.

Niepmann and Schmidt (2016) approach the topic from a different perspective. They analyze the letter of guarantees as a risk mitigating instrument for exporters and try to answer how banks affect export patterns through issuing these guarantee instruments. Their research show that a one-standard deviation negative shock to a country's supply of letter of credit reduces U.S exports to that country by 1.5 percentage points. Export to countries that are poorer and smaller, where fewer U.S. banks are active, are more affected when banks reduce their supply of trade finance. What Eximbanks perform for insuring the shipments substitute to what banks do in issuing letter of credits for exports. These two are competitors in terms of market structure as much as they are export promotion instruments.

\section{Data and Methodology}

\subsection{Data}

Our data is collected from various sources and covers period from 2000 to 2015. The details of variables are given in Table 1. We have 212 countries (Appendix A) for our analysis for 16 years that makes 3392 observations in total. $(\mathrm{N}=3392, \mathrm{n}=212, \mathrm{~T}=16)$. As our panel has many entities but few time periods it is a short balanced panel structure. Zero values are given 1 to allow logarithmic transformation for OLS and fixed effect estimation. Missing values and incorrect treatment of zero trade flows can produce severely biased results (Baldwin \& Taglioni, 2006) For this reason, we also applied Poisson PMLE method which allows zero trade.

To begin with, we use data on Turkish export provided by Turk Eximbank which is our dependent variable. Turk 
Eximbank insured shipments are the main independent variable (IV). A big portion of data is obtained from CEPIIs GeoDist data which makes available a set of gravity variables developed in Mayer and Zignago (2005). GDPs, Populations and Areas of the source and destination countries are used as proxy of economic size. Cost proxies like distance, time difference, and conflict and country risk are also obtained from CEPII Database. International trade volume is expected to be lower when the transaction costs get higher. Transaction costs change with the distance between trading partners. Moser, Nestmann and Wedow (2008) indicate that political risk is an important and robust determinant of export and should be taken into account in any empirical model of trade. Therefore, country risks of OECD classification is included in our analysis.

Many of the variables in this dataset is dyadic that it includes variables valid for pairs of countries like distance between two countries. We used weighted distance and Mayer and Zignago (2011) explains how weighted distances are calculated for the countries and why, in some countries, economic center is represented by another city due to being not populated enough for such a representation. Reel Effective Exchange Rate is obtained from World Bank. We also compared World Bank REER with Darvas (2012) but they appear similar in our graph analysis.

Table 1. Variables, type, description and source

\begin{tabular}{|c|c|c|c|}
\hline Variable & Type & Description & Source \\
\hline Export & Monadic & $\begin{array}{l}\text { Turkish export from } 2000 \text { to } 2015 \text { in logarithmic US\$. The } \\
\text { original WITS values have been added } 1 \text { USD to allow for } \\
\text { logarithmic transformation on zero-valued export. }\end{array}$ & WITS Database \\
\hline Eximbank Insurance & Monadic & $\begin{array}{l}\text { Turk Eximbank insured shipments from } 2000 \text { to } 2015 \text { in US\$. } \\
\text { Turk Eximbank values have been added } 1 \text { USD to allow for } \\
\text { logarithmic transformation on zero-valued export. }\end{array}$ & Turk Eximbank \\
\hline GDP Per Capita & Monadic & $\begin{array}{l}\text { Gross Domestic Product (GDP) Per Capita across country-pairs } \\
\text { in logarithmic US } \$ \text { is used for economic size. }\end{array}$ & CEPII Database \\
\hline Population & Monadic & Population of the countries, total in million & CEPII Database \\
\hline REER & Monadic & $\begin{array}{l}\text { Real Effective Exchange Rate: the nominal effective exchange } \\
\text { rate (a measure of the value of a currency against a weighted } \\
\text { average of several foreign currencies) divided by a price } \\
\text { deflator or index of costs. (Head \& Mayer, 2002) }\end{array}$ & World Bank \\
\hline Distance & Dyadic, Time Invariant & $\begin{array}{l}\text { Distance is a weighted measurement using latitudes, longitudes } \\
\text { and populations data of main agglomerations of all countries. } \\
\text { The general formula developed by (Head \& Mayer, 2002) }\end{array}$ & CEPII Database \\
\hline Area & Dyadic, Time Invariant & Logarithmic area of countries in square kms of the countries. & CEPII Database \\
\hline Time difference & Dyadic, Time Invariant & Number of hours difference between export and import & CEPII Database \\
\hline Landlocked & Dyadic, Time Invariant & Dummy variable indicating $1=$ Landlocked & CEPII Database \\
\hline Contiguity & Dyadic, Time Invariant & Dummy variable indicating $1=$ Contiguity & CEPII Database \\
\hline Common Religion & Dyadic, Time Invariant & Percentage in which both countries share religions & CEPII Database \\
\hline EU Membership & Dyadic, Time Variant & $\begin{array}{l}\text { Dummy variable indicating } 1=\text { Destination is a EU Member } \\
\text { (Appendix B) }\end{array}$ & $\begin{array}{l}\text { Compiled by } \\
\text { Authors }\end{array}$ \\
\hline Conflict & Dyadic, Time Variant & Dummy variable indicating $1=$ War & CEPII Database \\
\hline Country Risk & Dyadic, Time Variant & $\begin{array}{l}\text { Country Risk Classification of the Participants to the } \\
\text { Arrangement on Officially Supported Export Credits }\end{array}$ & OECD \\
\hline
\end{tabular}

Trade costs are also important part of the standard gravity models and usually bilateral distance is used in empirical studies as a proxy of trade costs. However, there are additional variables which are customarily used. Islands, landlocked countries and common borders (contiguity) are the dummy variables used to reflect the hypotheses that transport costs increase with distance and that they are higher for landlocked countries and islands but are lower for neighboring countries. (Bacchetta et al., 2012). Common religion, a percentage indicating that both countries share same religion and EU membership are also controlled.

\subsection{Methodology}

We employed a form of gravity model, the workhorse tool of empirical fields, which is popularly used from theory based to more exotic applications (Baldwin \& Taglioni, 2006). The gravity model has to come to be the starting point for a wide variety of research questions with a policy component. (Shepherd, 2013) The commencement of using the idea that the size of bilateral trade flows between a country pair can be approximated by a law called the "gravity equation" is the seminal work of Tinbergen (1962). A good discussion 
of the application of gravity models can be found in Bacchetta et al. (2012).

Egger and Url (2006), Moser, Nestmann and Wedow (2008) and Janda (2013) have applied the gravity model in the contexts of credit insurance. Head, Mayer and Ries (2010) follow a specification in their work where the gravity equation is combination of monadic effects and the dyadic effects. Dyadic effects are mainly the control variables and factors that affect trade costs between $i$ and $j$. Dyadic variables can be classified as time-invariant (distance, shared border, shared language etc.) and time-variant (belonging jointly to GATT/WTO or being EU member). The vector of dyadic variables contain all the "usual suspects" but the complete list remain incomplete. Unobserved dyadic linkages end up in the error term $\left(\mathrm{ui}_{\mathrm{j} t}\right)$. (Head et al., 2010).

As Head et al. (2010) indicate, for the value of $\mathrm{xi}_{\mathrm{jt}}$, the exports from exporting country $i$ to importing country $j$ in year $t$ can be represented in the following equation for the value. This is a well-known empirical and theoretical formulations of the gravity equation.

$$
X i_{j t}=G_{t} M_{i t}^{e x} M_{i t}^{i m} \varphi_{i j t}
$$

Where $\mathrm{M}_{\mathrm{it}}{ }^{\mathrm{ex}}$ and $\mathrm{M}_{\mathrm{it}}{ }^{\mathrm{im}}$ are indexes of the attributes of exporter $i$ and importer $j$ in a specific year. $\mathrm{G}_{\mathrm{t}}$ is the factor determining Eximbank insured shipments. $\mathrm{M}_{\mathrm{it}}{ }^{\mathrm{ex}}$ and $\mathrm{M}_{\mathrm{it}}{ }^{\mathrm{im}}$ are monadic effects and $\varphi_{\mathrm{ijt}}$ is the dyadic variables and represent observed and unobserved effects.

In practice, the gravity equation uses the variables in natural logarithm which allows an easy interpretation of the estimated parameters. Logarithmic transformations are convenient means of transforming a highly skewed variable into one that is more approximately normal. (Benoit, 2011) The logarithmic estimations are elasticities and indicates the percentage variation in trade following a 1 per cent increase in $\beta$. (Bacchetta et al., 2012). That is why we have log-log model mainly. Estimation of linear-log models for Poisson fixed effect and Poisson Pseudo Maximum Likelihood allow us to include zero values of Turkish Export in the analysis. Our general regression formulation is as follow.

$$
\begin{aligned}
\ln \left(\text { Exports }_{\mathrm{ijt}}\right)= & \alpha_{0}+\alpha_{1} \ln \left(\text { Exim }_{i t}\right)+\alpha_{2} \ln \left(\text { GDP } \text { cap }_{\mathrm{it}}\right)+\alpha_{3} \ln \left(\text { Pop }_{i t}\right)+\alpha_{4}\left(\text { reer }_{i}\right)+\alpha_{5}(\text { eu })+\alpha_{6}\left(\text { risk }_{\mathrm{it}}\right)+\alpha_{7}(\text { conflict })++\alpha_{8}\left(\text { dist }_{\mathrm{i}}\right)+ \\
& \alpha_{9}\left(\text { area }_{i t}\right)+\alpha_{10}\left(\text { tdiff }_{i t}\right)+\alpha_{11}\left(\text { landlocked }_{t}\right)+\alpha_{12}(\text { contig })+\alpha_{13}(\text { comrelig })+\varepsilon_{i t}
\end{aligned}
$$

Where $i$ denotes the exporting country, $j$ denotes the importer, $t$ denotes time, and $\ln ($.$) denotes the natural$ logarithm operator. $\varepsilon$ represents the omitted other influences on bilateral exports. Our parameter of interest is $\alpha_{1}$ and it represent public export credit insurance effect on exports holding other determinants of export constant.

\section{Diagnosis and Model Specifications}

Regression analysis using non-stationary variables may cause spurious regressions by providing significant $t$ and $F$ statistics and a high $R^{2}$ while there is no true relationship between the variables. (Gujarati, 2014). Therefore, we tested the variables under consideration for the stationary by using the augmented Dickey-Fuller test, Phillips-Perron tests and Pesaran's CADF tests. Although all of the tests conclude that the variables are stationary we only report the Pesaran's CADF in Table 2. The results can be seen below indicate that t-bar statistics have a higher critical value than cv10(\%90), cv5 (\%95) and cv1(\%99) confidence level statistics. The variables are stationary and we can proceed the following test to decide the convenient estimator.

Table 2. Pesaran's CADF test

\begin{tabular}{lccccll}
\hline TR_Export & $\mathrm{t}-\mathrm{bar}$ & $\mathrm{cv} 10$ & $\mathrm{cv} 5$ & $\mathrm{cv1}$ & Z[t-bar] & P-value \\
& -1.536 & -1.990 & -2.040 & -2.140 & 2.913 & 0.998 \\
\hline EXIM Insured Shipment & $\mathrm{t}-\mathrm{bar}$ & $\mathrm{cv} 10$ & $\mathrm{cv} 5$ & $\mathrm{cv} 1$ & Z[t-bar] & P-value \\
& -0.914 & -1.990 & -2.040 & -2.140 & 11.786 & 1.000 \\
\hline
\end{tabular}

Note. t-bar test, $\mathrm{N}, \mathrm{T}=(212,16) \quad$ Obs $=2544 \quad$ Augmented by 3 lags (average)

Cross-sectional average in first period extracted and extreme t-values truncated Deterministics chosen: constant.

We run $F$ test after fixed effect regression and the result of the test that all $\mathrm{u} \_\mathrm{i}=0: \mathrm{F}(185,2733)=37.15$; Prob $>\mathrm{F}$ $=0.0000$ means that the fixed effects are non-zero and pooled OLS will be biased. Likelihood-ratio test of sigma_u=0: $\operatorname{chibar} 2(01)=2238.90$ Prob $>=$ chibar $2=0.000$ also rejects $\mathrm{H}_{0}$ that classical model is not suitable for modelling as there are individual effects. We applied LR test to see if the panel effect are two dimensional, i.e individual or time, and the result rejects $\mathrm{H}_{0}$ hypothesis that at least one of the standard errors of individual and time effect is equal to zero.

Breusch and Pagan (1980) Lagrangian multiplier test for random effects has the null hypothesis in the LM test indicates that the variances across entities is zero. By estimating the following equation ln_TR_export[destination_name,t] $=\mathrm{Xb}+\mathrm{u}$ [destination_name $]+\mathrm{e}[$ destination_name,t] for $\operatorname{Var}(\mathrm{u})=0$, 
chibar2 $(01)=6604.52$ and Prob $>$ chibar2 $=0.0000$ means that there is no significant difference across countries . The test failed to reject the null therefore running a simple OLS is not convenient and the random effect model is able to deal with heterogeneity better than the pooled OLS. Checking the hypothesis of no random effects $(\operatorname{Var}(\mathrm{u}[\mathrm{i}])=0)$, and rejecting $\mathrm{H}_{0}$ indicates that there are individual effects. All of the above tests are weak in showing us if fixed or random effects are effective.

Conventionally, the Hausman test was used to identify the appropriate specification of the model between fixed or random effects. We applied the Hausman test and the test was inconsequential due to the violation of positive definite differences of variance. Result of the test failed to reject the null hypothesis of fixed effects vs. random effects. Instead, we used Schaffer, Stillman and others (2016) user written test, xtoverid in Stata. Sargan-Hansen statistics 57.330 (Chi-sq(8) P-value $=0.0000$ suggest fixed effect model as the extra restrictions imposed by random effect are rejected. Mundlak (1978) approach provide an alternative to the Hausman test. The result of that test by using robust estimator of the variance-covariance matrix suggests that time-invariant unobservables are related to our regressors and the fixed effect model is appropriate.

We applied the Wald test to see if the dummies for all years are equal to 0 . If so then no time fixed effects are needed. For that we applied testparm which is a joint test to see if the dummies for all years are equal to 0 , if they are then no time fixed effects are needed. Prob $>=0.000$ is smaller than alpha (0.05) Therefore Wald test did not fail to reject the null that the coefficients for all years are jointly equal to zero. Therefore time fixed effects are needed. Modified Wald test for groupwise heteroscedasticity in fixed effect regression model has the null hypothesis of homoscedasticity (constant variance). The result of the test rejects the null and there is heteroscedasticity. We calculated a modified Wald statistic for groupwise heteroscedasticity in the residuals of a fixed effect regression model, following Greene (2000) and the result confirms heteroscedastic. Wooldridge test for autocorrelation in panel date test also reveals that there is no first-order autocorrelation in our data.

\section{Estimation}

As Park (2011) indicates presenting all models, unless for comparison purposes, whether significant or not is a common error and should be avoided. Our regression diagnostics show us that individual effect $u_{i}$ does exist and OLS is not capable of producing efficient and consistent parameter estimates. Therefore our first specification in Table 3 column 1 pools data in a simple OLS just provided to allow us to compare results to those in the gravity equation literature. For our OLS we choose to apply robust option as a simple and effective way of fixing violations of the homoscedasticity assumption. We also clustered analysis depending on the distance, unique variable to each country pair, to allow correlation of the error terms within groups, as suggested in the literature. (Shepherd, 2013)

Table 3. Regression results

\begin{tabular}{|c|c|c|c|c|}
\hline & $\begin{array}{c}\text { (1) } \\
\text { Log of Turkish } \\
\text { Export } \\
\text { OLS } \\
\end{array}$ & $\begin{array}{c}\text { (2) } \\
\text { Log of Turkish } \\
\text { Export } \\
\text { Fixed Effect } \\
\end{array}$ & $\begin{array}{c}(3) \\
\text { Turkish Export with } 0 \\
\text { values } \\
\text { Poisson Fixed Effect }\end{array}$ & $\begin{array}{c}\text { (4) } \\
\text { Turkish Export } \\
\text { with } 0 \text { values } \\
\text { Poisson PML } \\
\end{array}$ \\
\hline Log of EXIMBANK Insured Export main & $\begin{array}{c}0.179^{* * * *} \\
(0.03)\end{array}$ & $\begin{array}{c}0.034^{* * *} \\
(0.01)\end{array}$ & $\begin{array}{c}0.044^{* * *} \\
(0.00)\end{array}$ & $\begin{array}{c}0.125^{* *} \\
(0.04)\end{array}$ \\
\hline Log of GDP per capita (current US\$) & $\begin{array}{c}1.023^{* * * *} \\
(0.20)\end{array}$ & $\begin{array}{c}1.160^{* * *} \\
(0.25)\end{array}$ & $\begin{array}{c}0.925^{* * *} \\
(0.00)\end{array}$ & $\begin{array}{c}0.989^{* * *} \\
(0.12)\end{array}$ \\
\hline Log of GDP per capita (current US\$) & $\begin{array}{c}0.608^{* * *} \\
(0.11)\end{array}$ & $\begin{array}{c}0.544^{* * *} \\
(0.09)\end{array}$ & $\begin{array}{c}0.714^{* * * *} \\
(0.00)\end{array}$ & $\begin{array}{c}0.579^{* * *} \\
(0.12)\end{array}$ \\
\hline Log of Population of Origin & $\begin{array}{l}0.608 \\
(1.54)\end{array}$ & $\begin{array}{l}2.322^{*} \\
(1.11)\end{array}$ & $\begin{array}{c}0.150^{* * *} \\
(0.00)\end{array}$ & $\begin{array}{l}1.210 \\
(0.91)\end{array}$ \\
\hline Log of Population of Destination & $\begin{array}{c}0.413^{* * *} \\
(0.10)\end{array}$ & $\begin{array}{c}1.336^{* * *} \\
(0.28)\end{array}$ & $\begin{array}{c}1.037^{* * * *} \\
(0.00)\end{array}$ & $\begin{array}{c}0.378^{* * *} \\
(0.10)\end{array}$ \\
\hline Real Effective Exhange Rate & $\begin{array}{r}-0.012^{*} \\
(0.01)\end{array}$ & $\begin{array}{r}-0.016^{*} \\
(0.01)\end{array}$ & $\begin{array}{c}-0.003^{* * *} \\
(0.00)\end{array}$ & $\begin{array}{l}-0.003 \\
(0.00)\end{array}$ \\
\hline $1=$ Destination is a EU member & $\begin{array}{l}1.159 \\
(0.77)\end{array}$ & $\begin{array}{l}-0.261 \\
(0.29)\end{array}$ & $\begin{array}{c}-0.248^{* * *} \\
(0.00)\end{array}$ & $\begin{array}{l}-0.098 \\
(0.22)\end{array}$ \\
\hline Country Risk & $\begin{array}{l}0.114 \\
(0.09)\end{array}$ & $\begin{array}{l}0.382 \\
(0.25)\end{array}$ & $\begin{array}{c}0.273^{* * *} \\
(0.00)\end{array}$ & $\begin{array}{l}-0.022 \\
(0.06)\end{array}$ \\
\hline $1=$ War & $\begin{array}{l}-0.300 \\
(0.84)\end{array}$ & $\begin{array}{c}0.000 \\
(.)\end{array}$ & & $\begin{array}{c}0.853^{* * *} \\
(0.22)\end{array}$ \\
\hline
\end{tabular}




\begin{tabular}{lccc}
\hline Weighted distance (pop-wt, km) & $-0.000^{* * *}$ & 0.000 & $-0.000^{* * *}$ \\
& $(0.00)$ & $()$. & $(0.00)$ \\
Log of area in sq. kms & $0.150^{*}$ & 0.000 & 0.137 \\
& $(0.07)$ & $()$. & $(0.07)$ \\
Time Difference (nbr of hours) & 0.093 & 0.000 & 0.079 \\
& $(0.07)$ & $()$. & $(0.07)$ \\
1=Landlocked & $-0.766^{* *}$ & 0.000 & 0.028 \\
& $(0.29)$ & $()$. & $(0.16)$ \\
1=Contiguity & -0.078 & 0.000 & $0.913^{* * *}$ \\
& $(0.98)$ & $()$. & $(0.21)$ \\
1=Common Religion & $0.949^{* *}$ & 0.000 & 0.393 \\
constant & $(0.34)$ & $()$. & $(0.24)$ \\
& -9.466 & $-18.255^{* * *}$ & $-10.074^{* *}$ \\
R-sqr & $(5.31)$ & $(3.46)$ & $(3.69)$ \\
dfres & 0.742 & 0.523 & 0.801 \\
BIC & 129 & 1901 & $2.0 \mathrm{e}+08$ \\
N & 7467.0 & 5269.1 & 2039.0 \\
r2 & 2039.0 & 2039.0 & 0.8 \\
\hline
\end{tabular}

${ }^{*} p<0.05,{ }^{* *} p<0.01,{ }^{* * *} p<0.001$.

The first estimate OLS model fits the data well: its $\mathrm{R}^{2}$ is 0.74 , meaning that the explanatory variables account for over 77 percent of the observed variation in DV. F-test is statistically significant and rejects the hypothesis that all coefficients are jointly zero at the 1 percent level. Looking at the estimated coefficients and the corresponding t-tests, OLS results in column one show that increases in Turk Eximbank insured shipments promotes Turkish export with 0.18 elasticities. Increases in exporter and importer country per capita income, importer population promote bilateral trade. Distance and real effective exchange rate reduce trade.

The second column of Table 3 gives the fixed effect estimation which allows us to identify the effects of variable that vary bilaterally. Therefore dummy variables that are collinear with the fixed effect will be automatically dropped from the model by Stata. Unobservable multilateral resistance can be accounted for by dummy variables by employing fixed effect but the drawback is that it is not possible to estimate a fixed effects model which includes data that only vary by exporter (constant across importer). In our analysis, conflict, distance, time difference, landlocked, contingency and common religion and area sqm2 of importer country have been omitted because of collinearity. Rho, interclass correlation says that $85 \%$ of the variance is due to differences across panels. Coefficients in the fixed effect (within) regression for Turk Eximbank insured shipments, both GDP per capita of the countries, population are significant and positive as expected. Reel Effective Exchange Rate is significant but has a negative coefficient. Turkish export is negatively related with the Reel Effective Exchange rate. If we change the exchange rate by 1 unit, we'd expect our variable to change by $1.9 \%$. The remaining common religion, EU membership of the destination country, country risks have not significant $\mathrm{P}$ values. The remaining dummy variables are omitted because of collinearity. Changing Turk Eximbank insured shipments by one percent, the fixed model result suggests that Turkish Export will increase $0.033 \%$. The other coefficients are also log-log and they show elasticities. Although not reported, we controlled for the time effect and found significant difference in years except 2007. Result shown in column 3 of Table 3 is estimated using Poisson fixed effect estimation which is an estimation that allows zero observations in dependent variable. Excluding constant within group variables, this estimator gives significant positive $\mathrm{P}$ values for Eximbank Insurance, GDP per capita and Population for both countries and country risk. Reel effective exchange rate and EU membership are also significant but with a negative coefficient.

Last estimation in Table 3 presents Poisson Pseudo Maximum Likelihood estimation which is different than Poisson estimation as it uses the method of Silva and Tenreyro (2010) and in that zero values are also allowed. The estimation result gives significant positive coefficients for Eximbank insured shipments, GDP per capita for the countries, population of the destination for monadic variables. Conflict and distance, contiguity are also significant. As Fally (2015) mentions Poisson-PML does not require the dependent variable to be Poisson distributed. The estimation procedure is fairly easy to implement and robust to misspecifications. This estimator allows us to incorporate observations with zero export as Poisson-PML is consistent with the presence of zero trade flows. Stata removes the variables if there is perfect collinearity. The area of the origin country is in such a situation and it is dropped from the analysis. Constant within group variables are dropped and the dependent 
variable in this specification is the yearly level of Turkish Export. All monadic variables are significant. Reel effective exchange rate and EU membership are significant but have negative coefficients. In this model, the higher country risk will also increase export by 0.27 unit. Table 4 gives the summary of significance and directions of the coefficients in the estimated models.

Table 4. Summary significance and directions of the coefficients

\begin{tabular}{|c|c|c|c|c|}
\hline & (1)OLS & (2)Fixed Effect & (3)Poisson Fixed Effect & (4)Poisson PML \\
\hline Log of EXIMBANK Insured Export main & $+{ }^{* * *}$ & $+t^{* * *}$ & $++^{* * * *}$ & $+{ }^{* *}$ \\
\hline Log of GDP per capita (current US\$) & $+* * *$ & $+* * *$ & $++^{* * * *}$ & $+^{* * * *}$ \\
\hline Log of GDP per capita (current US\$) & $+* * *$ & $+^{* * *}$ & $+^{* * *}$ & $+* * *$ \\
\hline Log of Population of Origin & & $+^{*}$ & $+^{* * *}$ & \\
\hline Log of Population of Destination & $+* * *$ & $+* * *$ & $+* * *$ & $+* * *$ \\
\hline Real Effective Exhange Rate & $-*$ & $-{ }^{*}$ & $-* * * *$ & \\
\hline $1=$ Destination is a EU member & & & $-* * * *$ & \\
\hline Country Risk & & & $+* * *$ & \\
\hline $1=$ War & & & & $+^{* * *}$ \\
\hline Weighted distance (pop-wt, km) &.$^{* * * *}$ & & &.$* * *$ \\
\hline $\log$ of area in sq. kms & $+^{*}$ & & & \\
\hline \multicolumn{5}{|l|}{ Time Difference (nbr of hours) } \\
\hline $1=$ Landlocked & $-^{* *}$ & & & \\
\hline 1=Contiguity & & & & $+* * *$ \\
\hline $1=$ Common Religion & $+^{* *}$ & & & \\
\hline
\end{tabular}

Note. Model 1 and 2 are Log-Log while Model 3 and 4 are Level-Log.

${ }^{*} p<0.05,{ }^{* *} p<0.01,{ }^{* * *} p<0.001$.

\section{Concluding Remarks}

Export promotion through export credit insurance is an important element in Turkey's export strategy. Our estimate of different panel gravity regressions for 212 countries and 16 years revealed that if we increase export credit insurance 1 percent, we'd expect Turkish export to increase between 3 percent to 17 percent depending on $\log -\log$ OLS and fixed effect results. The level-log estimations approve the effect that increasing export credit insurance one percent we can expect an increase in Turkish export between 4 percent to 12 percent, assuming other independent variables are held constant. Our analysis also shows that there are significant individual and time effects in panel data structure. Our control for lagged export credit insurance did not give any significant result.

\section{Acknowledgments}

We would like to thank for their personal assistance to Tuğba Solak, Neslihan Diniz for their precious inputs in manuscript preparation. We also would like to thank to Süleyman Şahal and İsmail Karadağ for their invaluable help in data preparation and data collection.

\section{References}

Abraham, F., \& Dewit, G. (2000). Export promotion via official export insurance. Open Economies Review, 11(1), 5-26. http://doi.org/10.1023/A:1008388511974

Agarwal, N., \& Wang, Z. (2016). Does the US EXIM Bank Really Promote US Exports? SSRN Electronic Journal, 12. http://doi.org/10.2139/ssrn.2816468

Ata, S. (2013). Türkiye ile Komşuları Arasındaki Ticaret Potansiyeli: Çekim Modeli Çerçevesinde Bir İnceleme Turkey's Trade with Neigbor Countries: A Gravity Model Analysis. In International Conference on Eurasian Economies, ss. 276 (Vol. 282, pp. 500-509).

Auboin, M. (2009). Boosting the availability of trade finance in the current crisis: Background analysis for a substantial G20 package. CEPR Policy Insight, 35.

Auboin, M., \& Engemann, M. (2014). Testing the trade credit and trade link: evidence from data on export credit insurance. Review of World Economics, 150(4), 715-743. http://doi.org/10.1007/s10290-014-0195-4

Bacchetta, M., Beverelli, C., Cadot, O., Fugazza, M., Grether, J. M., Helble, M., .. Piermartini, R. (2012). A Practical Guide to Trade Policy Analysis. World Trade Organization. Retrieved from https://www.wto.org/english/res_e/publications_e/wto_unctad12_e.pdf 
Badinger, H., \& Url, T. (2013). Export credit guarantees and export performance: Evidence from Austrian firm-level data. World Economy, 36(9), 1115-1130. http://doi.org/10.1111/twec.12085

Baldwin, R., \& Taglioni, D. (2006). Gravity for Dummies and Dummies for Gravity Equations. Cambridge, MA. http://doi.org/10.3386/w12516

Baltensperger, E., \& Herger, N. (2009). Exporting against risk? Theory and evidence from public export insurance schemes in OECD countries. Open Economies Review, 20(4), 545-563. http://doi.org/10.1007/s11079-007-9076-y

Benoit, K. (2011). Linear regression models with logarithmic transformations. London School of Economics, London.

Blackmon, P. (2014). Determinants of developing country debt: The revolving door of debt rescheduling through the Paris club and export credits. Third World Quarterly, 35(8), 1423-1440. http://dx.doi.org/10.1080/01436597.2014.946260

Brandi, C., \& Schmitz, B. (2015). Trade Flows in Developing Countries: What is the Role of Trade Finance? (pp. $1-25)$.

Breusch, T. S., \& Pagan, A. R. (1980). The Lagrange Multiplier Test and its Applications to Model Specification in Econometrics. The Review of Economic Studies, 47(1), 239. http://doi.org/10.2307/2297111

Brunner, H. P. (2015). Testing the Link between Accessible Export Finance and Insurance, and Regional Trade Growth in Africa and Asia: A Role for Regional Export Credit and Investment Guarantee Agency (ECIGA). Asian Development Bank Economics Working Paper Series, (433). http://doi.org/10.2139/ssrn.2568988

Darvas, Z. (2012). Real effective exchange rates for 178 countries: A new database.

Del Carmen García-Alonso, M., Levine, P., \& Morga, A. (2004). Export credit guarantees, moral hazard and exports quality. Bulletin of Economic Research, 56(4), 311-327. http://doi.org/10.1111/j.1467-8586.2004.00206.x

Eck, K., Engemann, M., \& Schnitzer, M. (2014). How trade credits foster exporting. Review of World Economics, 151(1), 73-101. http://doi.org/10.1007/s10290-014-0203-8

Egger, P., \& Url, T. (2006). Public Export Credit Guarantees and Foreign Trade Structure: Evidence from Austria. The World Economy, 29(4), 399-418. http://doi.org/10.1111/j.1467-9701.2006.00790.x

Fally, T. (2015). Structural Gravity and Fixed Effects. Journal of International Economics (Vol. 97). Cambridge, MA: Elsevier. http://doi.org/10.3386/w21212

Felbermayr, G. J., \& Yalcin, E. (2013). Export credit guarantees and export performance: An empirical analysis for Germany. World Economy, 36(8), 967-999. http://doi.org/10.1111/twec.12031

Greene, W. H. (2000). Econometric analysis (International edition).

Gujarati, D. (2014). Econometrics by example. Palgrave Macmillan.

Head, K., \& Mayer, T. (2002). Illusory border effects: Distance mismeasurement inflates estimates of home bias in trade (Vol. 1). Working Papers 2002-01, CEPII research center, CEPII Paris.

Head, K., Mayer, T., \& Ries, J. (2010). The erosion of colonial trade linkages after independence. Journal of International Economics, 81(1), 1-14. http://doi.org/10.1016/j.jinteco.2010.01.002

Herger, N., \& Lobsiger, M. (2010). How do Export Risk Guarantees affect Exports ?The Case of Switzerland. Aussenwirtschaft, 65, 297-310.

Janda, K., Michalikova, E., \& Skuhrovec, J. (2013). Credit support for export: Robust evidence from the Czech Republic. World Economy, 36(12), 1588-1610. http://doi.org/10.1111/twec.12061

Mah, J. S. (2006). The effect of export insurance subsidy on export supply: The experience of Japan. Journal of Asian Economics, 17(4), 646-652. http://doi.org/10.1016/j.asieco.2006.05.004

Manova, K., Wei, S. J., \& Zhang, Z. (2015). Firm exports and multinational activity under credit constraints. Review of Economics and Statistics, 97(3), 574-588. http://doi.org/10.3386/w16905

Mayer, T., \& Zignago, S. (2011). Notes on CEPII's distances measures: The GeoDist database.

Mayer, T., Zignago, (2005). Market access in global and regional trade (Vol. 2). CEPII Working Paper.

Moser, C., Nestmann, T., \& Wedow, M. (2008). Political risk and export promotion: Evidence from Germany. 
The World Economy, 31(6), 781-803. http://doi.org/10.1111/j.1467-9701.2008.01102.x

Mundlak, Y. (1978). On the pooling of time series and cross section data. Econometrica: Journal of the Econometric Society, 69-85.

Niepmann, F., \& Schmidt-Eisenlohr, T. (2016). No Guarantees, No Trade: How Banks Affect Export Patterns. International Finance Discussion Paper, 2016(1158), 1-61. http://doi.org/10.17016/IFDP.2016.1158

OECD. (2016). Arrangement on Officially Supported Export Credits (2016).

Park, H. M. (2011). Practical guides to panel data modeling: A step-by-step analysis using stata. Public Management and Policy Analysis Program, Graduate School of International Relations, International University of Japan.

Ross, D., \& Pike, R. H. (1997). Export credit risks and the trade credit offer: Some Canadian evidence. Journal of Multinational Financial Management, 7(1), 55-70. http://doi.org/10.1016/S1042-444X(97)00005-4

Schaffer, M. E., Stillman, S. et al. (2016). XTOVERID: Stata module to calculate tests of overidentifying restrictions after xtreg, xtivreg, xtivreg2, xthtaylor. Statistical Software Components.

Shepherd, B. (2013). The gravity model of international trade: A user guide. ARTNeT Gravity Modeling Initiative, United Nations, http://doi.org/10.1017/CBO9781107415324.004

Silva, J. M. C. S., \& Tenreyro, S. (2010). On the existence of the maximum likelihood estimates in Poisson regression. Economics Letters, 107(2), 310-312. https://doi.org/10.1016/j.econlet.2010.02.020

Tinbergen, J. (1962). Shaping the world economy; suggestions for an international economic policy. Books (Jan Tinbergen).

Turk Eximbank. (2016). Eximbank. Retrieved November 10, 2016, from http://www.eximbank.gov.tr/EN,1193/about-us.html

Turk Eximbank. (2017). Historical Overview. Retrieved March 7, 2017, from http://www.eximbank.gov.tr/EN,1196/history.html

Van der Veer, K. J. M. (2014). The Private Export Credit Insurance Effect on Trade. Journal of Risk and Insurance, 82, 601-624. http://doi.org/10.1111/jori.12034

\section{Appendix}

\section{Appendix A. Importer Countries}

\begin{tabular}{|c|c|c|c|}
\hline Afghanistan & Denmark & Lao PDR & Rwanda \\
\hline Albania & Djibouti & Latvia & Saint Helena \\
\hline Algeria & Dominica & Lebanon & Saint Pierre and Miquelon \\
\hline Andorra & Dominican Republic & Lesotho & Samoa \\
\hline Angola & East Timor & Liberia & San Marino \\
\hline Anguila & Ecuador & Libya & Sao Tome and Principe \\
\hline Antigua and Barbuda & Egypt, Arab Rep. & Lithuania & Saudi Arabia \\
\hline Argentina & El Salvador & Luxembourg & Senegal \\
\hline Armenia & Equatorial Guinea & Macao & Seychelles \\
\hline Aruba & Eritrea & Macedonia, FYR & Sierra Leone \\
\hline Australia & Estonia & Madagascar & Singapore \\
\hline Austria & Ethiopia & Malawi & Slovak Republic \\
\hline Azerbaijan & Faeroe Islands & Malaysia & Slovenia \\
\hline Bahamas, The & Falkland Island & Maldives & Solomon Islands \\
\hline Bahrain & Fiji & Mali & Somalia \\
\hline Bangladesh & Finland & Malta & South Africa \\
\hline Barbados & Fm Sudan & Marshall Islands & Spain \\
\hline Belarus & France & Mauritania & Sri Lanka \\
\hline Belgium & French Polynesia & Mauritius & St. Kitts and Nevis \\
\hline Belize & Gabon & Mexico & St. Lucia \\
\hline Benin & Gambia, The & Micronesia, Fed. Sts. & Vincent and the Grenadines \\
\hline Bermuda & Georgia & Moldova & Suriname \\
\hline Bhutan & Germany & Mongolia & Swaziland \\
\hline Bolivia & Ghana & Montserrat & Sweden \\
\hline Bosnia and Herzegovina & Gibraltar & Morocco & Switzerland \\
\hline
\end{tabular}




\begin{tabular}{|c|c|c|c|}
\hline Botswana & Greece & Mozambique & Syrian Arab Republic \\
\hline Brazil & Greenland & Myanmar & Tajikistan \\
\hline British Virgin Islands & Grenada & Namibia & Tanzania \\
\hline Brunei & Guatemala & Nauru & Thailand \\
\hline Bulgaria & Guinea & Nepal & Togo \\
\hline Burkina Faso & Guinea-Bissau & Netherlands & Tonga \\
\hline Burundi & Guyana & Netherlands Antilles & Trinidad and Tobago \\
\hline Cambodia & Haiti & New Caledonia & Tunisia \\
\hline Cameroon & Honduras & New Zealand & Turkmenistan \\
\hline Canada & Hong Kong, China & Nicaragua & Turks and Caicos Isl. \\
\hline Cape Verde & Hungary & Niger & Tuvalu \\
\hline Cayman Islands & Iceland & Nigeria & Uganda \\
\hline Central African Rep. & India & Norfolk Island & Ukraine \\
\hline Chad & Indonesia & Northern Mariana Islands & United Arab Emirates \\
\hline Chile & Iran, Islamic Rep. & Norway & United Kingdom \\
\hline China & Iraq & Oman & United States \\
\hline Christmas Island & Ireland & Pakistan & Uruguay \\
\hline Cocos (Keeling) Is. & Israel & Palau & Uzbekistan \\
\hline Colombia & Italy & Panama & Vanuatu \\
\hline Comoros & Jamaica & Papua New Guinea & Venezuela \\
\hline Congo, Dem. Rep. & Japan & Paraguay & Vietnam \\
\hline Congo, Rep. & Jordan & Peru & Wallis and Futura Isl. \\
\hline Cook Islands & Kazakhstan & Philippines & Yemen \\
\hline Costa Rica & Kenya & Pitcairn & Zambia \\
\hline Cote d'Ivoire & 2Kiribati & Poland & Zimbabwe \\
\hline Croatia & Korea, Dem. Rep. & Portugal & Rwanda \\
\hline Cuba & Korea, Rep. & Qatar & \\
\hline Cyprus & Kuwait & Romania & \\
\hline Czech Republic & Kyrgyz Republic & Russian Federation & \\
\hline
\end{tabular}

\section{Appendix B: The chronology of EU membership in our dataset}

2000: Austria, Belgium, Czech Republic, Denmark, Finland, France, Germany, Greece Ireland, Italy, Luxembourg, Netherlands, Portugal, Spain, Sweden, United Kingdom

2004: Cyprus, Estonia, Hungary, Latvia, Lithuania, Malta, Poland, Slovak Republic, Slovenia,

2007: Romania, Bulgaria

2013: Croatia

Appendix C: Correlation Table of the Variables

\begin{tabular}{|c|c|c|c|c|c|c|c|c|c|}
\hline & $\begin{array}{c}\text { Log TR } \\
\text { Export } \\
\end{array}$ & $\begin{array}{c}\text { Log } \\
\text { Exim }\end{array}$ & $\begin{array}{c}\text { Log } \\
\text { GDP_O }\end{array}$ & $\begin{array}{c}\text { Log } \\
\text { GDP_D }\end{array}$ & $\begin{array}{c}\text { Log } \\
\text { Pop O } \\
\end{array}$ & $\begin{array}{c}\text { Log } \\
\text { Pop D } \\
\end{array}$ & REER & EU & Risk \\
\hline Log TR Export & 10.000 & & & & & & & & \\
\hline Log Exim & $0.7975^{*}$ & 10.000 & & & & & & & \\
\hline Log GDP_O & $0.2064 *$ & $0.1170^{*}$ & 10.000 & & & & & & \\
\hline Log GDP_D & $0.3477^{*}$ & $0.3372 *$ & $0.2109 *$ & 10.000 & & & & & \\
\hline Log Pop O & $0.2046^{*}$ & $0.1408 *$ & $0.8476^{*}$ & $0.2027 *$ & 10.000 & & & & \\
\hline Log Pop D & $0.6511^{*}$ & $0.6396^{*}$ & $0.0607^{*}$ & $-0.1858 *$ & $0.0756^{*}$ & 10.000 & & & \\
\hline REER & $0.1433^{*}$ & $0.0591 *$ & $0.8341^{*}$ & $0.1549 *$ & $0.4714^{*}$ & 0.0312 & 10.000 & & \\
\hline $\mathbf{E U}$ & $0.3661^{*}$ & $0.3314^{*}$ & $0.0670^{*}$ & $0.4521 *$ & $0.0591^{*}$ & $0.1203^{*}$ & $0.0527^{*}$ & 10.000 & \\
\hline Risk & $-0.2303^{*}$ & $-0.3205^{*}$ & -0.0053 & $-0.5887 *$ & -0.0040 & $-0.0802 *$ & -0.0047 & $-0.1143^{*}$ & 10.000 \\
\hline Conflict & $0.1246^{*}$ & $0.1029 *$ & 0.0000 & 0.0304 & -0.0000 & $0.0590 *$ & 0.0000 & $0.0399 *$ & $0.0992 *$ \\
\hline Distance & $-0.5461 *$ & $-0.4620 *$ & -0.0000 & $-0.0622 *$ & -0.0000 & $-0.3269 *$ & -0.0000 & $-0.3700 *$ & $-0.1788 *$ \\
\hline Area_D & $0.5518^{*}$ & $0.5468 *$ & 0.0000 & $-0.2234 *$ & -0.0000 & $0.8495^{*}$ & 0.0000 & $0.0642 *$ & 0.0391 \\
\hline Time Diff. & $-0.4343^{*}$ & $-0.3654^{*}$ & -0.0000 & $0.0793 *$ & -0.0000 & $-0.3049 *$ & -0.0000 & $-0.3113^{*}$ & $-0.2318 *$ \\
\hline Landlocked & -0.0190 & $-0.0592 *$ & -0.0000 & $-0.2784 *$ & -0.0000 & $0.1208 *$ & 0.0000 & 0.0164 & $0.2149 *$ \\
\hline Contiguity & $0.1291^{*}$ & $0.1015^{*}$ & 0.0000 & -0.0062 & -0.0000 & $0.0935^{*}$ & -0.0000 & $0.0511 *$ & $0.0522 *$ \\
\hline Common Rel & 0.0187 & $0.0481 *$ & 0.0000 & $0.1808 *$ & 0.0000 & -0.0155 & 0.0000 & -0.0190 & 0.0397 \\
\hline
\end{tabular}




\begin{tabular}{lccccccc}
\hline & Conflict & Distance & Area_D & Time Diff. & Landlocked & Contiguity & Common Rel \\
\hline Conflict & 10.000 & & & & & & \\
Distance & $-0.2670^{*}$ & 10.000 & & & & & \\
Area_D & $0.0575^{*}$ & $-0.3071^{*}$ & 10.000 & & & & \\
Time Diff. & $-0.2067^{*}$ & $0.9018^{*}$ & $-0.3202^{*}$ & 10.000 & & & \\
Landlocked & 0.0294 & $-0.2226^{*}$ & $0.1983^{*}$ & $-0.2499^{*}$ & 10.000 & & \\
Contiguity & $0.4494^{*}$ & $-0.2477^{*}$ & $0.0774^{*}$ & $-0.1629^{*}$ & $0.0423^{*}$ & 10.000 & 10.000 \\
Common Rel & -0.0248 & -0.0165 & $0.0486^{*}$ & 0.0071 & $-0.0533^{*}$ & -0.0234 & \\
\hline
\end{tabular}

\section{Copyrights}

Copyright for this article is retained by the author(s), with first publication rights granted to the journal.

This is an open-access article distributed under the terms and conditions of the Creative Commons Attribution license (http://creativecommons.org/licenses/by/4.0/). 